\title{
The work of memory: embodiment, materiality and home in Jeanne Bouvier's autobiographical writings
}

Maria Tamboukou, Centre for Narrative Research, University of East London, UK

Abstract: In this paper I follow trails in the memory of work by reading the books and papers of Jeanne Bouvier, a French seamstress, ardent trade-unionist and passionate writer, who left a rich body of labour literature including four published historical studies, as well as the memoirs of her life, work and struggles. Work, action and creativity are three interrelated planes on which Bouvier situates herself, while memory and imagination are interwoven in the way she seeks to understand herself in the world with others. What emerges as a particularly striking theme from Bouvier's papers is a material matrix of mnemonic and imaginary practices, wherein bodies, places and objects are entangled in the narrative constitution of the self of the woman worker/writer.

Key words: material entanglements, embodiment, imagination, memory of work, woman worker, worker writer.

\section{Jeanne Bouvier: a woman worker writer}

During many years, I carried out regular research [...] I was interested in this intellectual work that brought me satisfaction every day. I was also learning so many interesting things, that I had never thought about; I found such a big number of documents, either in the National Library, or in the National Archives [...] The study of questions around work and particularly women's work is exciting; and it has its rewards as long as the researcher manages to reconstitute a past of struggles, of injustices and miseries that workers or a category of employers had to endure. ${ }^{1}$

In the last pages of her Mémoires, Jeanne Bouvier (1865-1964), a French seamstress, who became a worker at the age of eleven and later an ardent tradeunionist in the French garment industry, forcefully expresses the pleasures of intellectual work that she immersed into during the fifty-nine years of her long working life and after she had stepped down from her leading position in the Confederation General du Travail (CGT) in 1923. Bouvier's agonistic politics went hand in hand with hard work and intense intellectual activities, all beautifully recounted in her book, Mes Mémoires: Une syndicaliste féministe, 1876-1935. This was the last volume she published in 1936, after a series of four historical studies on women's work, economics and politics. ${ }^{2}$

But what were the conditions of possibility for such creative forces to be unleashed? As Bouvier wrote in her memoirs, it was the law that regulated the eight hour work day after the First World War, that allowed workers time for intellectual activities. ${ }^{3}$ Moreover, it was also after the war that Georges Renard, professor of labour history at the Collège de France, took over the task of editing the publication of 58 volumes comprising La Bibliothèque sociale des métiers [The 
Social library of trades]. There were seven volumes on women in this collection, ${ }^{4}$ but Bouvier was the only woman worker, who was asked to write the history of the lingères. ${ }^{5}$ As the spirit of the collection was that all volumes were to be written by field experts, the fact that Bouvier was chosen was not surprising: she was a militant activist in the lingerie trade union, and a leading figure in the French federation of garment workers; but of course the invitation to write a book made her feel utterly out of her depths: 'When alone, I was thinking: 'M. Georges Renard has been deluded about my value and my knowledges. No, it is not possible for me to accept to write a book, I have always suffered by my ignorance. ${ }^{6}$

Despite the difficulties, Bouvier threw herself in the pleasures of research and produced a rare study of the French linen-goods industry in the twentieth century that has become an invaluable source in women's labour history. ${ }^{7}$ You have written a book and you will write others', , Renard had told her when she delivered her manuscript and indeed research and writing became Bouvier's life-long passion. Thus, even after she had written her four historical studies and had retired from a long working life, she went on working at the National Library: 'as soon as I had some free moments, I would go into the temple of wisdom [...] I was envying the privileged ones who had acquired a solid instruction and could devote their whole time in doing research. ${ }^{9}$ Still throughout her life she had learnt how to 'be content with little ${ }^{10}$ and she thought that she was one of the few women who had passed their life in the industry but had discovered freedom in the spaces of the National Library.

Being an intellectual worker was not an easy subject position to inhabit, but as Jacques Rancière has argued in his analysis of the French workers' cultural worlds in the nineteenth century, it was not only through open confrontation, but actually through their entanglement and conversations with bourgeois values, worlds and ideas that workers intervened in the socio-political and cultural formations of their times. ${ }^{11}$ This encounter with 'the bourgeois other' ${ }^{12}$ was a recurrent theme of the seamstresses' experience, since they were in constant contact with the bourgeois women whose dresses they were making. In her historical study of the French seamstresses in pre-revolutionary France, Clare Crowston $^{13}$ has particularly discussed the cross-cultural encounters that the seamstresses' guild had facilitated and the way such encounters became a route for a culture of femininity to be developed and transferred across class lines. Through intense archival work into women's personal documents, Crowston has shown that many seamstresses crossed gendered lines of work and family and many of them chose to remain single and live independent lives. As Bouvier has recounted in her memoirs, it was through her conversations with enlightened bourgeois women that she learnt about trade-unionism and feminism as options in her struggling life:

In 1897, a feminist journal was launched by Mme Marguerite Durand: La Fronde, a daily edition on feminist rights [...] One of my clients. Mme Norat was an ardent feminist. She became an assiduous reader of this journal and while I was trying her dresses, she was talking to me about women's rights and the injustices of the law with regard to women. In this way, every fitting session was a lesson in feminism [...] One day she told me: 'I am surprised that an intelligent woman like you has not subscribed to the union of your trade [...] This invitation to unionise seemed to me extraordinary. Unionise, me? Why? I confess that I did not understand anything. ${ }^{14}$ 
Despite her initial hesitations, Bouvier not only joined the union, but soon climbed its hierarchy and became one of its few women leading figures, not only in France but in the international workers' movement. Her papers include innumerable letters from women trade unionists all over the world she was in correspondence with throughout her life; many of these women would arrange to meet her in person, whenever they visited Paris. ${ }^{15}$ For Bouvier, working and developing personal friendships with a network of international women was amongst the pleasures of being a feminist and a trade-unionist. After all, it was these friendships and connections that kept her going through her harsh times with her comrades in France. Like many other women trade unionists Bouvier fell out with the CGT leadership and stepped down as a vice president of the International Committee of Labour in 1923, but soon after this crisis, she threw herself into writing. As with other women labour organisers in the US, like Rose Pesotta and Fannia Mary Cohn, ${ }^{16}$ writing became for Bouvier not just a life passion, but also a way of talking back as a single woman to her social world in general and to her comrades in particular. 'How I became a trade unionist' is a lengthy chapter in her memoirs recounting her adventures and struggles in the union but concealing and silencing many of its internal conflicts. ${ }^{17}$

But apart from the pleasures that Bouvier felt in researching and writing, her five books are rare records of the memory of work written by a woman worker. Once published they were read by a wider community of readers interested in women's labour history, but have also become very useful references and sources for a number of academics and research students all over the world, now and then. Her papers at the Bibliothèque Historique de la ville de Pario (BHDP) include a series of lengthy letters from researchers asking her advice mostly about women's work, well before any of her own books were published. ${ }^{18}$ Bouvier was also a frequent contributor of articles to a range of labour and feminist newspapers, journals and magazines, such as, La Française, L' Hôtel-café Restaurant, Le Peuple, Journal des Dames des PTT and Peuple amongst others. What is particularly striking is that her articles cover a wide variety of themes and topics not necessarily restricted within the history of women's work as well as Bouvier's life long concern with the problem of home-based work - le travail a domicile. ${ }^{19}$ She was interested amongst others in the problem of children's criminality and overall welfare, the protection of young workers, the history of shoemaking, the origins of coffee in France and the first coffee shop in Paris, the lighting of Paris, the history of wine and the problems of intellectual workers. ${ }^{20}$

In thus drawing on Bouvier's rich body of labour literature and particularly her Mémoires, in this paper I look at traces in 'the memory of work', a theme that has recently opened up interesting debates in an interdisciplinary field of inquiries including amongst others, industrial archeology, museum studies, anthropology, history, sociology, geography and town planning. ${ }^{21}$ As the relevant literature in this field indicates it is the minutiae and forgotten details of the world of work that allow glimpses in its past; such 'moments of being' in the culture of work can be beautifully captured in the workers' narratives. 


\section{The Gender of Memory}

Memory culture, as well as the politics of mnemonic practices is currently a booming interdisciplinary field, ${ }^{22}$ but with some notable exceptions, the gender of memory is a rather dim area within it. ${ }^{23}$ 'How can the category of gender be integrated into debates on memory culture?' Sylvia Paletschek and Sylvia Schrant have asked in introducing their 2008 volume, The Gender of Memory, where important themes around gender and memory are addressed. It is this unlit area in memory studies that I want to throw light on, by reading the memoirs of a woman worker, writer and political activist. As already noted above, the culture of work is a relatively new area within the wider field of memory studies and yet the neglect of gender is already visible in its current developments, which mostly focus on the study and recovery of industrial environments and installations, ${ }^{24}$ while women are again invisible or marginalised in the contents and forms of representation of the memory culture of the world of work. ${ }^{25}$

In this light how is gender entangled in the work of memory? Research findings from the study of oral history interviews ${ }^{26}$ but also from women's autobiographical writings ${ }^{27}$ show that women tend to weave their memories around the I/you relationship. This relational aspect of memory is further linked to the well-rehearsed personal/political assemblage, the fact that political events cannot be separated from subjective experiences in women's lives and beyond. In this context, a rich body of feminist literature has already established that events within the family and the close community play a much greater role in women's mnemonic practices. ${ }^{28}$ Bouvier's Mémoires for example start with the baptism and death of her little brother, ${ }^{29}$ while the years of her carefree childhood are narrated in the context of her family home and village, which become recurrent themes throughout her Mémoires.

What also stands out in research and study of women's archives in the world of work is the amount of 'memory work' that many women had to do in collecting and preserving their personal and political documents and literally creating their own archives. Memory work in the form of 'archiving the self', was thus an agonistic endeavour, intentional and strategic as I will further show, and not an involuntary process in its Proustian conceptualisation. It goes without saying that practices of selection and deselection were intensely at work in these endeavours and such 'archives of the self' should be considered in the light of the discursive limitations that have created their conditions of possibility. But these are limitations that are at play for any archive and there is a rich body of literature that has looked at the multi-faceted layers of the archive as a symbol and repository of power/knowledge, an institution of governmentality and most importantly, a laboratory of memory [and forgetting] par excellence. ${ }^{30}$ What I therefore suggest is that the autobiographical character of such 'archival technologies of the self $f^{31}$, is a particularly gendered theme, since it is women who are usually forgotten or hidden in history and particularly single women, like Bouvier, who felt the need to take care of their legacy because if they didn't, nobody would. This theme of the discursive construction of the female self as an archive is a practice that opens up analytical possibilities where technologies of autobiography, or what Leigh Gilmore has theorised as 'autobiographics, ${ }^{32}$ make connections with gendered mnemonic practices and the politics of writing histories.

Indeed Bouvier worked tirelessly to ensure that her memories and personal documents of a long life as a worker, intellectual and activist would find a place in 
the archives and possibly histories of the future: she thus bequeathed all her papers to the Bouglé Library, where she had spent many evenings as a reader herself, in the course of her studies. Bouvier knew Marie-Louise Bouglé ${ }^{33}$ and had followed her tireless efforts to create a feminist archive though hard voluntary work for many years between 1921 and her premature death in 1936. The two women had a warm correspondence and they occasionally met and had interesting discussions. Bouvier was thus fully aware of 'the memory work' that she had to put in place, so that she could have a place in the records of a feminist history in the making. Her correspondence with André Mariani, curator of the Library after Bouglé's death, shows how anxious she was that her papers should be deposited at the library and they would be well placed and looked after: 'We have taken good care of your documents [...] we have reserved the best place for them in the bookcase [...] you are in a way so present in the library that I cannot imagine why you should not be interested in it any more ${ }^{34}$, Mariani wrote to Bouvier in June 1937, reassuring her concerns about the fate of her papers. Here it is striking to note that despite her efforts, Bouvier was completely forgotten by the time of her death and while she is now a well recognised figure in labour history her books have never been translated in English, apart from some extracts from her memoir that have been included in Mark Traugott's French workers' lives anthology. ${ }^{35}$

In light of the above, what I therefore argue is that it is in Bouvier's 'archival technologies of the self' - the collection of documents that she has carefully collected as 'her fonds' in the Bouglé Library - that we mostly trace gender entanglements in the memory of work. These documents include: the manuscripts of her four published historical studies as well as of her Mémoires; ${ }^{36}$ her correspondence with trade unionists, intellectuals and writers all over the world; ${ }^{37} \mathrm{a}$ wide collection of journal and newspaper articles from and about her as well as the themes she was interested in, ${ }^{38}$ and last but not least a rich file of her life-long passionate interest on the problem of home-based work, le travail a domicile. ${ }^{39}$ Interestingly enough 'the persona' that her Mémoires present is that of 'une syndicaliste féministe', while actual memories of work as labour, only appear in the first part, where she recounts her childhood.

It is therefore from the subject position of a feminist trade-unionist that she wrote her Mémoires, and not as a seamstress, although her position as a workerintellectual is prominently flagged-up as unique and exceptional. This is how she presented herself in an autobiographical extract that was included in an article that Huguette Champu wrote about her work in La Française on November 17, 1928:

I believe I am the only worker who has become a writer. Margueritte Audoux, ${ }^{40}$ who is also a seamstress is a novelist, but I feel attracted by historical research. More specifically I direct my studies on issues of women workers. $^{41}$

What emerges here is a theme that Rancière has mostly discussed and theorised in his analyses of the French workers' writings: their desire to change their lives in 'the here and now' of their actuality, appropriate bourgeois values and possibilities, claim the right to think, create and write and thus radically disrupt the distribution of the sensible, le partage du sensible - that is the cultural order of what can be seen and done and of who has the right to be included and appreciated in the community of writers/artists/intellectuals. ${ }^{42}$ Radically disrupting traditions in social history that have argued that 'the vocation of workers is to work [...] and to 
struggle and that they have no time to waste playing at flâneurs, writers or thinkers ${ }^{43}$ Rancière has provocatively argued that the division between the intellectual as thinker and the worker as doer cannot be grasped or contested by historical interpretations framed within the analytics of workers' resistance. 'The worker, who without having learnt to spell, tried his hands at making verses to the taste of the day, was perhaps more dangerous for the existing ideological order than the one who sang revolutionary songs', Rancière has boldly suggested. ${ }^{44}$ But once crossing the boundaries of the forbidden world of culture, workers have also loathed as well as written against the drudgery of the world of labour, which they were no more willing to embrace or cherish. Louis Gabriel Gauny's labour chronicle on the torturous passage of time vividly inscribes such experiences:

When he arrives at the place, the battle begins. [...] Given over momentarily to the inner satisfaction of useful work, he forgets his surroundings. His arms work, some craft detail is done pleasingly, he keeps going. An hour slips by [...] For a moment he manages to distance himself from the resentful feelings of his implacable memory. He works furiously. A living machine, he gains for the profit of his proprietor what he loses at the expense of his own strength. ${ }^{45}$

Although Bouvier worked as a seamstress till the end of her life, she combined work with writing and political activism, as she had no other means of supporting herself. In writing her Mémoires, however, it was her persona as an intellectual worker that she wanted to put forward and unlike Gauny above, she wrote very little about the actual experience of the needle labour. Her case is not unique: my research with the letters and personal writings of Désirée Véret-Gay and Marie-Reine Guindorf - the two seamstresses who founded La Femme Libre, the first feminist newspaper in nineteenth century France ${ }^{46}$ - has not found any memories of their actual labour apart from the fact that it supported their writing and that it was long and tiresome. ${ }^{47}$ Within the context of such discursive limitations, memories of work can be traced in the first part of Bouvier's memoir, in her study of La lingerie et les lingères ${ }^{48}$ as well as in the bulk of her writings around home-based work - le travail a domicile. ${ }^{49}$ Since memory and imagination have been theorised as 'alternative but complementary fates of perception', ${ }^{50}$ in reading Bouvier's writings I look at the materiality of memory and imagination and particularly the entanglement of places, bodies and objects.

\section{Writing the memory of work}

Bouvier published her Mémoires in 1936, before finally retiring at La Maison Galignani-a retreat home where intellectuals could be admitted for free-in Neuilly-sur-Seine. ${ }^{51}$ At the time that she decided to write her Mémoires she had already become a public figure and short biographical sketches of hers had already been published in a range of newspaper articles that she had very carefully selected and kept in her papers. Thus, while her story had been told, retold and written about over the years in fragments, her Mémoires was an opportunity to leave a definitive image of herself in the archives of the future.

As a literary text, her Mémoires is a moving testimony of a woman worker's life that captivates the reader from its very beginning. Part I, 'Mon enfance' unfolds as a story of her childhood in the countryside, the village of Salaize-sur-Senne, in 
the department of Isère. As already noted above, the narrative starts with her earliest memory of the baptism of her baby brother, recounts her carefree years of her childhood and finally the disaster that befell upon her family due to the phylloxera infestation, the selling of their house and belongings and their migration to a nearby village, Saint-Symphorien-d'Orzon, where she started working in a silk-throwing factory at the age of eleven years old. If we consider that Bouvier wrote her memoirs when she was already seventy years old, the vividness of the memory images she creates in writing about her childhood is striking. Memory is intimately intertwined with writing: we remember as we write about our past and remembrance always happens in the now of writing or telling. While reading Bouvier's memoirs we have the sense that we live with her in the village of her childhood: we are drawn in the past that she reconstitutes by writing memory, as surely she would have relived her childhood while remembering and writing about it. Her memoir thus becomes a plane for visceral memories to erupt, both for its writer and readers, but how is gender entangled in this mnemonic mode and how does it relate to the memory of work? I want to consider these questions within a materialistic reconceptualisation of memory where bodies, places and objects open up new analytical tropes in how we understand and make sense of mnemonic practices.

\section{a) Body memory and memories of the body}

Despite its multiple entanglements with writing, as well as a long tradition of theorising memory as a mental activity, matter has ultimately come to matter in memory studies today. In theorising the materiality of memory Edward Casey has argued that not only memory is much more than a mental activity, but more importantly, 'body memory takes precedence over mind and mentality', while 'the absence of body memory would amount to the devastation of memory altogether. ${ }^{, 52}$ In positing this argument, Casey draws on Whitehead's notion of causal efficacy, 'the hand of the settled past in the formation of the present. ${ }^{.53}$ Causal efficacy comes from the outside, revealing the worldly conditions that we emerge from: causation emerges not as a logical mode-the way we think about the world-but as a visceral, living mode, the way we live the world. In this context the body becomes 'a material condition of possibility for remembering. ${ }^{.54}$

Bouvier's body is indeed central in her memory work: we meet and drift away with the body of the child who climbs trees, despises soup, tends the cows, finds lentils exotic and loathes sewing. ${ }^{55}$ Moreover we tremble and shake with her while her mother wakes her up:

My mum used to wake me up before dawn. She was calling me many times, without succeeding to wake me up. Tired of calling me without result, she was taking me all asleep and was making me stand in front of the bed. I was shaking and sometimes crying, so much I was suffering from being obliged to wake up, while I had such a great need to sleep. I was dressing up in pain, without being completely awake and I was leaving fighting against the desire to sleep, which was not leaving me for a long time after leaving home. One cannot imagine what a child suffers to be ripped from sleep. ${ }^{56}$

'The body re-enacts the past, with no need to represent it ${ }^{57}$, Casey has suggested and we surely have this almost filmic scene of re-enactement in imagining a young girl crying and shaking while being woken up to go to work. Casey has 
further argued that the notion of 'body memory' raises questions around how we remember 'by, in and through the body', but while it makes connections with memories of the body 'as the accusative object of our awareness', the two should not be conflated. ${ }^{58}$ Although Casey has noted that this difference between 'body memory' and 'memory of the body' is 'blurring and difficult to discern', ${ }^{59}$ what I suggest is that this difference is only a heuristic one - helpful in terms of analysis but untenable otherwise. Bouvier's memoir vividly shows that it is through entanglements and 'intra-actions' ${ }^{\prime}$ between the worker's body, which both remembers and is remembered that memories of work erupt, take shape and are narrativised through writing. This means that body memories and memories of the body do not pre-exist as entities, but are rather constituted through their intraaction.

In this context Bouvier's traumatic memories of the sleepless body is a component of the collective memory of sleeplessness that emerges from a long history in the seamstresses' labour. Indeed, the sleepless and exhausted seamstress has become a central figure in a series of cultural representations in paintings, poems and novels, ${ }^{61}$ but has also been trapped and framed within the discourse of the defenceless victim. ${ }^{62}$ There were of course material conditions that created conditions of possibility for such discourses to emerge and circulate widely: the seasonal character of the seamstress' work - busy in spring and autumn and hence the need to work at night - while slack for several months in winter and summer. As Bouvier later recounts in her memoirs, so important was the need for working at night that many Parisian ateliers would keep their workers till late without doing nothing, even in the slow season, just to construct and maintain a market reputation of being extremely busy and presumably good:

In this atelier they used to make us work very late, without having dinner [...] these late nights would go on till two o'clock in the morning [and] they imposed on us an absolute silence. But why would they make the workers work late? One would think that they had numerous orders [...] not at all. We worked late so that $[\ldots]$ the atelier would seem overflowing with work and its good name would become known throughout Paris. ${ }^{63}$

Working at night, was also a consequence of the fact that most seamstresses worked at home, either exclusively or on top of their work at the atelier or the factory. Sleeplessness is therefore a particularly gendered experience in the memory of work. Moreover, the visceral way that the sleepless body comes alive in women's narratives from the memory of work, brings to the fore other reasons for going sleepless - quite simply low wages and the need to take on extra work, which is another important aspect in the memory of work:

I was obliged to work outside the factory once my thirteen-hour day was over. I did crochet work and often stayed up all night. I worked night after night, so there would be bread in the house. Despite these sleepless nights, often there was no bread.

I remember one time amongst others when I stayed nearly two days without eating. That evening when I came home from the factory, I started to work. My mother spent the night with me, shaking me whenever, in spite of myself, I began to fall asleep. She was telling me, 'Don't fall asleep. You know very well that you mustn't sleep. Tomorrow we won't have any bread.' I was 
making superhuman efforts to stay awake. It was very cold. Snow was falling against the window panes. Despite all these tortures I continued to work until four thirty in the morning, at which time I got ready to return to the factory. ${ }^{64}$

Apart from sleeplessness, what is also inscribed in the above extract from Bouvier's memoir, is the body of the woman worker feeling cold and hungry, experiences and memories that are by no means exclusively gendered. However the striking image of Bouvier's mother shaking her daughter's body in agony to keep her awake so that she could go on working for the sake of the family's bread, forcefully brings in gendered experiences in the memory of work: a young working girl feeling exhausted, hungry, cold and unprotected in her own home, which is also her workplace. What I therefore argue is that the home/work continuum creates conditions of possibility for gendered entanglements in the memory of work to be traced and it is particularly relevant to the study of the seamstresses' work, given their low wages, as well as the seasonal character of the garment trade as already discussed above. As Bouvier's Mémoires recount, well after her childhood and while she had established herself as a successful Parisian dressmaker, she would still have to combine work at the atelier and work at home within the home/work continuum:

For some time I had clients who would have me work at their homes during the dead season. I would thus escape the period of unemployment, which gave me a certain comfort. In this way, I never missed work. But during the high season, these clients brought me additional work. Apart from the days spent at the atelier, I always had some orders to do at home to satisfy my personal clientele. After my workday I therefore had to impose on myself long late-night vigils. My time was divided up like that: get up at four o'clock; work at home until eight, then get ready and have breakfast within half and hour; at eight-thirty leave for the atelier, where I arrived at nine o'clock and got out only at eight or nine in the evening. I would rush home, eat dinner in a hurry, and get back to work until midnight, when I finally went to bed, to sleep till four o'clock the morning. ${ }^{65}$

Bouvier's past is thus embodied in her actions: memories of extreme poverty in her childhood motivate her to work hard even when she does not absolutely need it, for the sake of safety and security in the unforeseeable future. As Bergson has argued, the body creates a plane of action continually crossing boundaries between the future and the past. ${ }^{66}$ Moreover the possibility of working around the clock was linked to the fact that she only had herself to look after, but was also related to the fear that in her old age she would have nobody to care for her. In this light the need to fight for the regulation and protection of home-based work-le travail a domicile - became Bouvier's passion throughout her life.

Of course men have also historically worked at home-based sweatshops; but unlike women who have welcomed it as a possibility, its drudgeries notwithstanding, men have always resisted work at home. As Joan Scott ${ }^{67}$ has shown in her study of the politics of work and family in the nineteenth century Parisian trades, working at home was not a central issue or a problem per se for the Parisian seamstress: it was the regulation of work at home and particularly higher wages that they were keen to pursue, as such arrangements not only enabled them to work and look after their family, but they were also safeguarding their professional identity as qualified seamstresses. Tailors on the other hand were very 
much against home-based work and fought for work to be done only at workshops. In their discourse, it was the shop-based work that protected their professional identity and not the level of the wages. ${ }^{68}$ There is a distinct gender issue here, which as Scott has noted has been largely ignored by labour historians: the way home has been historically constituted as a desired work place for women and has thus created conditions of possibility for waged and unwaged labour to be conflated for women till our own days. ${ }^{69}$ Considering home as a place of work for women brings forward the salience of places and spaces in the materiality of memory, a theme that I will discuss next.

\section{a) Remembering places, implaced memories}

Spaces and places, as well as power relations and forces of desire revolving around them are constitutive of human perception and powerful in the interweaving of practices of memory, forgetting and imagination. As Casey has pithily put it: 'memory of place implaces us and thus empowers us: gives us space to be. ${ }^{70}$ It is no wonder then that throughout her Mémoires, Bouvier's memories of her homeland, Dauphiné inspire and shape the way she writes about her working life, while the memory of her home becomes an anchoring point in the process of remembering and imagining, 'one of the greatest powers of integration for the thoughts, memories and dreams of mankind', according to Bachelard. ${ }^{71}$ Indeed, the fact that unlike the other sections in the memoir, Bouvier recounts the moment of leaving in the present tense is particularly striking:

It is the end, nothing is left. The house is empty. We leave it. [...] I still contemplate it: the shutters, the doors are closed: everything is sad [...] Life does not exist any more in this house [...] It looks like a tomb. Seeing this, my heart sinks. I leave it behind, sobbing as I am going away. ${ }^{72}$

Bouvier's deserted house in the village of her childhood is a deeply moving image that concludes the chapter on the family disaster, but also becomes a recurring theme throughout her memoirs. While working hard, first in the silkthrowing factory as a child, after that in a series of positions in domestic service throughout her teenage years and finally as a qualified seamstress in Paris ${ }^{73}$, Bouvier was nurturing a sweet dream: to save money, buy a house and return to the country again: 'Yes, I was dreaming of a house with a garden where I would grow vegetables and flowers, where I would raise chickens and rabbits. That way I would spend my old age in sweet peace. ${ }^{74}$ 'Imagining arises constantly in the midst of concrete actions ${ }^{75}$ Casey has commented. Thus, for Bouvier imagining a house in the country was erupting from her memories of the lost house of her childhood: her dream was of an object lost and yet still to come, the Kantian type of reproductive imagination, fusing together memory and anticipation. This dream was never realised, but it nevertheless unleashed existential forces that kept her in work and action throughout her life: 'To realise this dream, I had to pull the needle hard, and so I pulled it with fervour, ${ }^{76}$ she wrote in the concluding paragraphs of Part I, before going on to write the story of how she became a member of the syndicalist movement in Part II, and finally the story of how she became a writer, in Part III.

But why are places so important in mnemonic practices and how do they particularly relate to the memory of work? When we consider place memories we should conceptualise them in a two-fold way: as memories of a given place and memories occurring in that place, Casey notes. ${ }^{77}$ Again, the two modes are 
interrelated and cannot be disentangled, but they are useful in making sense of the salience of gender. We remember places more easily: no matter how mobile we are, the geography of our past can be charted and remembered in a more or less tangible way, while the times or moments of our lives are much more difficult to be seized, frozen and/or remembered. In this context, places create a plane of consistency, continuity and orientation for our lives and therefore place memory determines our place in the world, while remembering is an act of re-experiencing, but also of re-implacing, that is re-experiencing past places, Casey has aptly suggested. ${ }^{78}$

What we therefore have in the existing literature around the memory of work is 'the factory' as a mnemonic site par excellence: here there is a particular focus on questions around the preservation of deserted factories and industrial sites as monuments of the memory of work that is fading away. In this light, it is no wonder that industrial archaeology and urban and museum studies are important disciplinary areas in the newly emerging field of the memory of work. ${ }^{79} \mathrm{We}$ are further all familiar with a range of documentaries about deserted industrial sites and places, as well as attempts to keep them and often transpose them in museum, galleries or community spaces in keeping the memory of work alive. But what we have in Bouvier's memory is 'home' emerging not only as a lost object of desire, but also as a significant worksite of her life - significant and yet silenced — an existential platform from which she remembers her past and imagines her future. Feminist geographers have looked at how places are filled with human interpretation and significance, invested with strong emotions, but also shaped by intense gendered power relations at play. ${ }^{80}$ Either being attached to places or escaping from them, women have created rich fictional as well as autobiographical geographies, where Virginia Woolf's 'room of one's own'81 as a place of both domesticity and creativity has often become a memory of 'a studio of one's own' in women artists narratives ${ }^{82}$ as well as an atelier/workshop of one's own in women workers' narratives, as in Bouvier's memoir.

But unlike the Woolfian nostalgic image of 'a room of one's own', home strikingly emerges as a site of traumatic memories for Bouvier, a place where she often felt unprotected, hungry, cold, sleepless and overworked, a place to leave and not to stay. 'I have no home. I could not have one as I had to earn my bread' 83 she wrote in a newspaper article in 1922 in response to her comrades in the labour movement who had argued that women should stay at home and make it a haven in the world of capitalist exploitation. There is actually a haunting section in her memoirs, where she describes an adventure of running away from her family home, spending a night of wild wandering, as he could not bear her family's extreme poverty and destitution, despite her own hard work at the factory:

As the night fell, I took off. After having walked for some time, I found myself in a plane in the middle of the night; but it was a night lighted by a moon that looked diminutively large and with a clarity that made me afraid. Further on there was a wood with gigantic trees; a terrible silence: it seemed to me that I was alone in the world [and] I don't know whether my fright was because of the moon, the wood, the solitude or my shadow. ${ }^{84}$

It was against the backdrop of such traumatic memories that having 'a home of her own' became a life-long desire, a dream she sacrificed so much for, but which was sadly never realised. What she was able to secure through a life's hard work 
however was a Parisian flat at 10bis rue Antoinette, at the heart of the touristic Montmartre today, but a working class area, as well as a bohemian artists' colony in Bouvier's days. ${ }^{85}$ While reading her papers and particularly her letters I was actually struck by the persistence of the same address -10 bis rue Antoinette throughout her life. Bouvier worked hard to find a respectable place and in her memoirs she has recounted how she started in a small attic room and worked hard to save money so that she could move to a room with a fire-place, a street view, and water supply in the courtyard:

I continued to live frugally and was still doing extra work to keep myself afloat. I wanted to move for I wanted a room with a fireplace. Yes I wanted to offer myself the luxury of a fireplace [...] The moment came, when I could finally move and I had a fireplace in my room and also a cupboard [...] When I had moved in the concierge told me "I have a little side board in your room. If it is not in your way, I will leave it." I was delighted: a sideboard, a fireplace, a cupboard, a storage space and water; it was really too much! I could not believe I had so much luxury. ${ }^{86}$

Bouvier's excitement at having a fire-place, as well as some simple furniture pieces now brings in objects in considering the materiality of memory.

\section{c) Objects and/in memory}

With time I had succeeded in becoming a good seamstress. I no longer had difficulty executing the work that was entrusted to me. But I continued taking on extra work. I needed so many things: underwear and clothes, and then I was nourishing the project of having a wardrobe with a mirror!' ${ }^{87}$

A wardrobe with a mirror was indeed a desired object par excellence in the Parisian feminine bourgeois world, whose aesthetic pleasures Bouvier was working for, but which she also wanted to taste, appropriate them for herself. While reading this desire for a wardrobe with a mirror I could not help juxtaposing with the letters of Gwen John (1876-1939), a Welsh expatriate artist, who moved to Paris in 1904 and stayed there for the rest of her life: 'I've got an armoire a glace which is a wardrobe with shelves and a glace front, and white lace curtains at the window yes I am Parisienne and I feel more at home with the French than the English now'. ${ }^{88}$ But while for a bohemian artist like John acquiring 'an armoir a glace' was an aesthetic symbol of becoming French, for Bouvier it was an object congealing a worker's struggle to become respectable.

Objects in place congeal the places we remember, they 'put the past in place [and] are the primary source of its concrete implacement in memory', Casey has suggested. ${ }^{89}$ Surely Bouvier's excitement over her newly acquired furniture she had worked so hard for was connected to a sweet memory of an object that had warmed her heart and body during the harsh years of her childhood labour:

At eight o'clock we left the factory to have breakfast. I rushed home to finish my work. There were a few details to finish up before rushing to deliver it at last so that I could get the pay that would allow the whole household to eat. [...] The lady paid me seven francs, just as she had promised. Because it was 
very cold, she offered me a cup of coffee with milk to warm me up. The coffee was served in a beautiful white cup and saucer. This cup had a gilt garland (what a pretty cup) and the coffee was delicious and hot. I did not really like coffee and milk, but this coffee served in such a beautiful cup, I liked it very much! I left the lady's house feeling happy. ${ }^{90}$

What erupts in the torturous story of remembering being sleepless, tired, cold and hungry is the happiness of having coffee in a beautiful cup. 'Material things not only frequently constitute the specific content of places and memories alike, but by their special memorability they draw memory and place together in a quite significant way', Casey has suggested. ${ }^{91}$ We can see this assemblage of places and objects in the story of the pretty cup above, vividly inscribed in the memory of a young working girl alongside the harsh experiences of feeling tired, cold and hungry. But as a beautiful object, the coffee-cup not only congeals the past, but it also becomes an imaginary referent of a different world that is possible. Pure possibility differs both from necessity-something that must happen-and actuality, something that has happened. It is precisely in its independence from what has or can be actualised that the freedom of pure possibility lies. Bouvier's memory of 'the pretty cup' as a desirable domestic object would actually become a recurrent theme in her memoirs, particularly in the way she has recounted her experiences of creating a home for herself in Paris, as already discussed above.

\section{Sound silences in the memory of work}

The overarching ambience in the memory of work is saturated with frustration, tiredness and unhappiness: 'Either in the atelier or at home the workers have been very unhappy since the Middle Ages', Bouvier wrote in her study of the lingères, citing at full length Thomas Hood's Song of the Shirt, to flag the international character of the drudgery of the needlewoman's work. ${ }^{92}$ It is perhaps because of this unhappiness that both in her memoirs as well as in the study of the lingères we read very little about the embodied experience of sewing itself-with the exception of a section in her childhood where she writes how sewing was utterly boring for her. ${ }^{93}$ Sewing was more or less a skill that workers had to acquire and do, the Bergsonian type of habit memory and not something worth writing about. It was rather the horrible economics of the trade - the low wages, the long hours of work and the unhealthy conditions of the ateliers or their homes - that Bouvier wrote about and like the seamstresses of the of the nineteenth century romantic socialist movements sought to reform and regulate.

This absence of writing about the labour process itself is not unusual or surprising. In writing about a photographic project on women's work, Jo Stanley has highlighted women workers' surprise when asked if they had photographs of themselves at work: 'Pictures of me? At work? Well I don't think so dear [...] I have got plenty of me with the girls from work, but when we go out, but nothing in the factory, you know. Well you wouldn't, why bother? ${ }^{94}$ I think it is the 'why bother' question, namely the fact that the actual process of labour is something that most workers do to survive and they don't consider it worth remembering or capturing.

Like Stanley's participants, who had many photographs 'with the girls from work', Bouvier has written about how she had always enjoyed the company of 
fellow workers, while working as a milliner first and as a seamstress after that: 'I found many young women of my age at the atelier. I became friends with one of them very soon and we were not preoccupied at all with what the other workers did or said. ${ }^{95}$ Young women's friendship is indeed a constant theme in the diaries and memoirs of seamstresses, since the closed circle of the atelier has historically created conditions of possibility for friendship and comradeship to flourish and develop and it is perhaps one of the few aspects that lightens up the greyness and boredom of labour that many workers like Bouvier, did not want to remember or write about.

\section{Remembering / Imagining}

In writing her Memoirs at the end of a long working life, Bouvier chose three themes to structure her life document: harsh memories of work, political activism both as a trade-unionist and as a feminist_-and research and writing. Work, action and creativity thus constitute a plane of consistency for the woman-worker-activistwriter to emerge from, while memory and imagination are tightly interwoven in the unfolding of her narrative. In remembering we come back to the things that matter and in doing so our experience is ultimately transformed, Casey has commented. ${ }^{96}$ It is in this process of transformation that memory and imagination are inextricably interwoven. While we remember, we need not determined by the past, as we are always free to re-imagine our future since 'rather than a mere repository of experience, remembering becomes a continually growing fund for experience', Casey has aptly noted. ${ }^{97}$ Bouvier's Mémoires are indeed structured along this image of remembering as 'a baso continuo for much of human experience'. ${ }^{98}$ The harsh memories of working hard and of being tired, sleepless, cold and hungry, became the grounds of her militancy and political activism, that were catalytic in the many changes that happened in workers' lives in France and all over the world in the first half of the twentieth century. Moreover these experiences created a fertile ground for imaginative and creative forces to be unleashed in terms of the studies that Bouvier undertook in gendering the histories of the labour movement. But apart from intervening in the cultural formations of the twentieth century, research and writing have also opened up possibilities of freedom for Bouvier. Although by remembering we create a unity of existential understanding, memories also unleash lines of flight, which take us from the grounds where we stand and into the world, where everything is possible. As Bouvier has beautifully put it:

In the midst of material difficulties there remained a big, a very big satisfaction: to be able to indulge in intellectual work and more particularly in research that has allowed me to write my four volumes. One cannot have everything: material goods and intellectual satisfaction; I much prefer the latter. ${ }^{99}$

\section{Acknowledgements}

I would like to thank the archivists and librarians of la Bibliothe`que Historique de la Ville de Paris for facilitating my research with Bouvier's papers in May-June 2012 and for kindly giving me permission to quote from her papers. Thanks also to the University of East London for funding my archival research in Paris. 
1 Jeanne Bouvier (1983/1936) Mes Mémoires: Une syndicaliste féministe, 1876-1935 (Paris : La Découverte/Maspero), pp. 216, 227. All translations are mine. 2 Jeanne Bouvier (1927) Deux époques, deux hommes (Paris : Radot) ; (1928) La lingerie et les lingères (Paris: G. Doin) ; (1930) Histoire des dammes employées dans les postes, télégraphes et telephones, de 1714 a 1929 (Paris : Les Presses Universitaires de France); (1931) Les femmes pendant la révolution (Paris : E. Figuière).

${ }^{3}$ Bouvier, Mes Mémoires, p.213

${ }^{4}$ The titles of the 7 volumes commissioned to women are very interesting in terms of gendered cultural politics, yet the mere fact that women were considered is I think important in the context of its geographies and times: La Lingerie (Jeanne Bouvier); Fleurs, plumes, modes (Marguerite Boural); La dentelle (Mathilde Parat); Les gens de maison (Mme Moll-Weiss); L'Instutrice (Marguerite Bodin); Tabac et allumettes (Mme Claude Réal); Le Cinéma (Mme Germaine Dulac)

${ }^{5}$ In the vocabulary of Bouvier's time the lingère was the seamstress who sew garments of all kinds as well as other textile products, while the couturière was the dressmaker, who made women's clothing only and was considered more qualified and better paid than the lingère.

${ }^{6}$ Bouvier, Mes Mémoires, p.214.

${ }^{7}$ For commentaries about Bouvier's work, see amongst others, Judith Coffin (1996) The Politics of Women's Work: The Parisian Garment Trades, 1750-1914.

(Princeton: Princeton University Press) and Nancy Green (1997). Ready to Wear, Ready to Work: A Century of Industry Immigrants in Paris and New York. (Durham and London: Duke University Press).

${ }^{8}$ Bouvier, Mes Mémoires, p.216.

${ }^{9}$ Bouvier, Mes Mémoires, p.233.

${ }^{10}$ Bouvier, Mes Mémoires, p.233.

11 Jaques Rancière (2012). Proletarian Nights: The Workers' Dream in NineteenthCentury France. (London: Verso).

${ }^{12}$ Donald, Reid (2012). 'Introduction'. In Rancière, Proletarian Nights, p.xxi.

13 Claire Haru Crowston (2001) Fabricating Women: The Seamstresses of Old Regime France, 1675-1791. (London and Durham: Duke University Press).

${ }^{14}$ Bouvier, Mes Mémoires, p.101.

15 See Bibliothèque Historique de la Ville de Paris, Archives Marie-Louise Bouglé, Fonds Jeanne Bouvier, Boite 17, Correspondence. (BHVP/AMB/FJB/B17/Cor)

${ }^{16}$ See Maria Tamboukou (2013) 'Educating the seamstress: studying and writing the memory of work', History of Education, 42.4, 509-527 and (2014) 'The autobiographical you: letters in the gendered politics of the labour movement', Journal of Gender Studies, on-line first.

${ }^{17}$ Bouvier, Mes Mémoires, pp.101-210.

${ }^{18}$ See: BHVP/AMB/FJB/B17/Cor

${ }^{19}$ In her important work on The politics of women's work, Judith Coffin has translated the term 'travail a domicile as 'industrial homework'.

${ }^{20}$ For a rich collection of her articles, see: BHVP/AMB/FJB/B20/Divers.

${ }^{21}$ See Juan José Castillo (2004) 'La memoria del trabajo y el futuro del patrimonio', en Sociología del Trabajo, nueva época, n. 52, 3-37; Castillo (2008) La soledad del trabajador globalizado. Memoria, presente, futuro (Madrid: La Catarata; Castillo (2011) 'The Memory of Work and the Future of Industrial Heritage: New Issues Five Years Later [40 paragraphs]. Forum Qualitative 
Sozialforschung / Forum: Qualitative SocialResearch, 12(3), Art. 3, http://nbnresolving.de/urn:nbn:de:0114-fqs110333 (accessed, 24-3-2014).

${ }^{22}$ For an excellent overview of the field see amongst others, Susannah Radstone and Bill Schwarz (Eds) (2010) Memory: Histories, Theories, Debates. (NY: Fordham University Press).

${ }^{23}$ See, Susannah Radstone (2007) The Sexual Politics of Time: Confession, Nostalgia, Memory. (NY and London: Routledge) and Sylvia Paletschek and Sylvia Schrant (Eds.) (2008) The Gender of Memory: Cultures of Remembrance in Nineteenth and Twentieth Century Europe (Chicago: Chicago University Press).

${ }^{24}$ See Castillo, The memory of work, p.1.

${ }^{25}$ For example, the word 'femme' does not appear in any of the front pages of the website of the national archives of the world of work in France. See,

http://www.archivesnationales.culture.gouv.fr/camt

${ }^{26}$ See, Paletschek and Schrant, The Gender of Memory, p. 273

${ }^{27}$ For an excellent collection of theories around women's autobiographical writings, see Sidonie Smith and Julia Watson (Eds)(1998) Women, Autobiography, Theory: A Reader. (Madison: University of Wisconsin Press).

${ }^{28}$ See amongst others The Gender of Memory for a good overview of this literature.

${ }^{29}$ See, 'Le baptême du petite frère' and 'La mort du petite frère' as the very first pages/sections of her Mémoires, pp. 35-37.

${ }^{30}$ See amongst others, Arlette Farge (1989) Le goût de l'archive. (Paris: Gallimard); Jaques Derrida (1998) Archive Fever. (Chicago: The University of Chicago Press); Carolyn Steedman (2001) Dust. (Manchester: Manchester University Pres); Antoinette Burton (Ed.) (2005) Archive Stories: Facts, Fictions and the Writing of History. (Durham: Duke University Press); Ann, L., Stoler, (2009) Along the Archival Grain: Epistemic Anxieties and Colonial Common Sense (Princeton: Princeton University Press).

31 See Maria Tamboukou (2014) 'The female self as punctum: Fannia Cohn's archival technologies of the self', in British Sociological Association Auto/biography Yearbook, VIII, 99-13.

${ }^{32}$ According to Gillmore, 'autobiographics' is a discursive regime where narratives of experience are intervoven with discourses of truth in the autobiographical representation of the self. See, Leigh Gillmore (1994) Autobiographics: A feminist Theory of Women's Self-Representation. (Ithaca and London: Cornell University Press).

${ }^{33}$ Marie-Louise Bouglé (1883-1936) was an active feminist at the turn of the twentieth century. She worked as a secretary, but in 1921 she began an intense archival work, collecting materials about and around women, including books, journal articles, pamphlets, essays, studies, as well as personal correspondences. She thus founded a feminist library, which opened in 1923 and run on a voluntary basis, open to readers twice a week. After her premature death in 1936, her husband André Mariani looked after the library but it eventually became part of La Bibliothèque historique de la ville de Paris in 1946 and can today be located as: Archives Marie-Louise Bouglé, Bibliothèque Historique de la ville de Paris (BHVP/AMB). See, Maïté Albistur (1985) 'Une nouvelle demeure de Clio ou les archives Marie-Louise Bouglé', Matériaux pour l'bistoire de notre temps, vol. 1, $\mathrm{n}^{\circ} 1$ and Joan, W. Scott (1987). 'New Documents on the Lives of French Women: The Journal of 
Caroline B., 1864-1868. Signs: Journal of Women in Culture and Society. Vol.12, no 3, 568-572.

${ }^{34}$ André Mariani to Jeanne Bouvier, letter dated 6 June, 1937, BHVP/AMB/FJB/B17/Cor.

${ }^{35}$ Mark Traugott (1993). The French Worker. Autobiographies from the Early Industrial Era. (Berkeley: University of California Press).

${ }^{36} \mathrm{BHVP} / \mathrm{AMB} / \mathrm{FJB} / \mathrm{B} 9-16$

${ }^{37} \mathrm{BHVP} / \mathrm{AMB} / \mathrm{FJB} / \mathrm{B} 17 /$ Correspondence.

${ }^{38} \mathrm{BHVP} / \mathrm{AMB} / \mathrm{FJB} / \mathrm{B} 20-23 /$ Divers.

${ }^{39} \mathrm{BHVP} / \mathrm{AMB} / \mathrm{FJB} / \mathrm{B} 18 / \mathrm{Le}$ Travail a domicile.

${ }^{40}$ Margueritte Audoux (1863-1937) was a seamstress and novelist. Her most well known work is the autobiographical novel, Marie Claire, first published in 1910, where she describes the harsh years of her childhood and adolescence. For a critical discussion of Audoux's work, see Bernard Garreau (1991) Marguerite Audoux, la couturière des lettres (Paris: Tallandier).

${ }^{41}$ La Française, 17-11-1928, BHVP/AMB/FJB/B20/Divers.

42 Jacques Rancière (2009) The politics of aesthetics. London: Continuum.

43 Rancière, Proletarian Nights, p. viii.

${ }^{44}$ Jacques Rancière (2011) Staging the people: the proletarian and bis double, London: Verso, p.181

${ }^{45}$ Louis Gabriel Gauny, 'Le travail a la journée' cited in Rancière, Proletarian Nighto, p.59.

${ }^{46}$ La Femme Libre changed many names in the course of its two years history (18321834) and was eventually named Tribune des Femmes. For a rich presentation and discussion of the Tribune des Femmes, see amongst others, Claire Goldberg Moses and Leslie Wahl Rabine(1993) Feminism, Socialism and French Romanticism.

(Bloomington and Indianapolis: Indiana University Press).

47 See Maria Tamboukou (forthcoming), Sewing, Fighting and Writing: Radical

Practices in Work Politics and Culture, London: Rowman \& Littlefield.

48 See, Bouvier, La lingerie et les lingères, but also her notes on the manuscript at $\mathrm{BHVP} / \mathrm{AMB} / \mathrm{F} . J \mathrm{~B} / \mathrm{B} 10-12 /$ La lingerie et les lingères.

49 BHVP/AMB/F.JB/B18/Le Travail a domicile.

50 Edward, C. Casey (1976) Imagining: A Phenomenological Study (Bloomington: Indiana University Press), p.ix.

51 Bouvier's papers and particularly her letters show that she worked hard to be admitted to this home, a sign of her great anxiety about securing care for her old age, BHVP/AMB/FJB/B17/Cor.

${ }^{52}$ Edward Casey (2000) Remembering: A Phenomenological Study. Second edition.

(Bloomington: Indiana University Press), pp.172, 147.

53 Alfred Whitehead (1964/1920) The Concept of Nature (Cambridge: Cambridge University Press), p.50.

54 Casey, Remembering, 175.

55 Bouvier, Mes Mémoires, pp. 39-55.

${ }^{56}$ Bouvier, Mes Mémoires, p. 48.

57 Casey, Remembering, p.178

${ }^{58}$ Casey, Remembering, p.147

${ }^{59}$ Casey, Remembering, p.147 
${ }^{60}$ I refer here to Karen Barad's norion of 'intra-actions' denoting complex relations that constitute entities through their interrelation. See Karen Barad (2007). Meeting the Universe Halfway: quantum physics and the entanglement of matter and meaning.

(Durham and London: Duke University Press.)

${ }^{61}$ See: Lynn Alexander (Ed.) (2003) Women, Work and Representation: Needlewomen in Victorian Art and Literature. (Athens: Ohio University Press) and Beth Harris (Ed.) (2005) Famine and Fasbion (Aldershot: Ashgate).

62 See Helen Rogers for an interesting critique of the victimisation of the Victorian seamstress: (1997) 'The Good Are Not Always Powerful, Nor the Powerful Always Good': The Politics of Women's Needlework in Mid-Victorian London', Victorian Studies, 40.1, 589-623.

63 Bouvier, Mes Mémoires, p. 88.

${ }^{64}$ Bouvier, Mes Mémoires, p. 59.

${ }^{65}$ Bouvier, Mes Mémoires, pp. 97-98.

66 Henri Bergson, Matter and Memory (2002/1896). (London: Zone Books), particularly chapter 3, 'Of the survival of images', pp. 133-177.

${ }^{67}$ Joan Scott, 'Work identities for men and women: the politics of work and family in the Parisian trades in 1848'. In Gender and the Politics of History (New York: Columbia University Press), pp. 93-112.

68 See also Green, Ready to Wear, Ready to work for an interesting discussion of how such debates went on in the trade unions of the garment industry Paris and New York in the first half of the twentieth century.

69 Scott, 'Work identities for men and women', p.93.

70 Casey, Remembering, p. 215.

${ }^{71}$ Gaston Bachelard (1994) The Poetics of Space. (Boston: Beacon Press), p. 6.

${ }^{72}$ Bouvier, Mes Mémoires, pp. 55-56.

${ }^{73}$ As Deborah Simonton has noted, shifting from domestic service to needlework was a common trend among young working girls in pre-industrial Europe. See Simonton (2004) 'Earning and Learning: girlhood in pre-industrial Europe' in Women's History Review, Vol.13 (3), 363-386.

${ }^{74}$ Bouvier, Mes Mémoires, p.98.

${ }^{75}$ Casey, Imagining, p.3

${ }^{76}$ Bouvier, Mes Mémoires, p.98.

${ }^{77}$ Casey, Remembering, p. 33.

${ }^{78}$ Casey, Remembering, p.201.

79 See, Castillo, 'The Memory of Work'.

${ }^{80}$ See amongst others, Gillian Rose (1993) Feminism and Geography: The Limits of Geographical Knowledge, (Cambridge: Polity Press); Doreen Massey (1994) Space, Place and Gender, (Cambridge: Polity Press); Linda McDowell (1999) Gender, Identity and Place, Understanding Feminist Geographies, (Cambridge: Polity Press). See also a rich range of articles in the journal Gender, Place and Culture for historical and contemporary debates in the field.

${ }^{81}$ Virginia Woolf (1945) A Room of One's Own, (Harmondsworth: Penguin).

82 See Maria Tamboukou (2012) 'Heterotopic and Holey Spaces as Tents for the Nomad: Re-reading Gwen John's letters', Gender, Place and Culture: a Journal of Feminist Geography, 19.3, 275-290.

$83 \mathrm{BHVP} / \mathrm{AMB} / \mathrm{FJB} / \mathrm{B} 20 /$ Divers.

${ }^{84}$ Bouvier, Mes Mémoires, pp. 58-59. 
${ }^{85}$ Today 'Rue Antoinette' is called 'Rue Yvonne le Tac'. See http://www.cparama.com/forum/paris-rue-antoinette-t12007.html for images of the street in Bouvier's days.

${ }^{86}$ Bouvier, Mes Mémoires, p. 88.

${ }^{87}$ Bouvier, Mes Mémoires, p. 89.

${ }^{88}$ Gwen John to Charles McEvoy, undated letter, in Ceridwen Lloyd-Morgan (2004) Gwen Jobn: Letters and Notebooks (London: Tate Publishing), p. 40.

${ }^{89}$ Casey, Remembering, p. 206.

${ }^{90}$ Bouvier, Mes Mémoires, p. 60.

${ }^{91}$ Casey, Remembering, p. 205.

92 Bouvier, La Lingerie, p. 253-254, 256.

93 Bouvier, Mes Mémoires, p. 55.

94 Jo Stanley, (1991)'Well who'd want an old picture of me at work?' In J. Spence \& P. Holland (Eds.), Family snaps: The meaning of domestic photography (pp. 60-71). (London: Virago Press), p.60

${ }^{95}$ Bouvier, Mes Mémoires, p.81.

${ }^{96}$ Casey, Remembering, p. xxii.

${ }^{97}$ Casey, Remembering, p.284.

${ }^{98}$ Casey, Remembering, p.285.

${ }^{99}$ Bouvier, Mes Mémoires, p. 183. 